\title{
Immigration and Poverty Reduction: Policy Making on a Squirrel Wheel
}

\section{Vernon M. Briggs, Jr.}

The Economic Opportunity Act of 1964 (EOA), which launched the War on Poverty in the United States, was more than a major accomplishment of the Great Society's political agenda. It marked the beginning of "a new approach to poverty" (Levitan 1969). Until that time, the nation's efforts to combat poverty had focused almost exclusively on relicf measures. With the passage of the EOA, a new tactic was undertaken: prevention. As President Lyndon Johnson declared upon signing this legislation, "Our American answer to poverty is not to make the poor more secure in their poverty but to reach down and help lift themselves out of the ruts of poverty" (10). The causes of poverty in the United States were to be identified and then specific policies enacted to eliminate them. Attention was disproportionately given to measures to eradicate youth poverty, which was identified as the weakest link in the cycle whereby one generation of the poor becomes the next. If pursued vigorously, this approach-it was proclaimed by the original director of the program, R. Sargent Shriver-could eliminate poverty in the United States by 1976 (69).

In 1964, there were 36.4 million persons in the United States living in poverty (19.0 percent of the population). By 2001 the poverty population totaled 32.9 million persons (11.7 percent of the population). Thus, while the percentage of the poverty population has declined over the preceding 37 years, the absolute size of the poverty population itself has hardly shrunk (Census Bureau 2002a, 21). Clearly, the poor are still very much "with us." Indeed, in 2001 the nation's poverty population grew by 1.3 million persons-the largest annual increase in a decade.

The author is Professor of Labor Economics at the New York State School of Industrial and Labor Relations at Comell University, Ithaca, N.Y. The paper was presented at the annual meeting of the Association for Evolutionary Economics at Washington, D.C., on January 4, 2003. 
There are many reasons that Shriver's goal of poverty elimination has proven to be elusive. It is not the purpose of this undertaking to recount them. It is instead to identify one causative factor of mass poverty that was virtually unknown in 1964 but, over the intervening years, has become a major contributor to its perpetuation. It is the effects of the revival of mass immigration as manifested by immigration policies enacted by the federal government since 1965.

\section{The Return of Mass Immigration}

As shown in table 1, immigration had been of declining significance to the U.S. economy (in terms of percentage of the population) since 1910 and in absolute number terms since 1930. By 1965, the percentage of the population that was foreign born had fallen to 4.4 percent-the lowest percentage in all of U.S. history-and the absolute number of immigrants had declined to levels not seen since the $1880 \mathrm{~s}$. Immigration had fallen so far by the mid 1960 s that, for all intents and purposes, it was an irrelevant concern for economic policy making.

With regard to the link to poverty, the limited immigration that had taken place for the 35 years immediately before 1965 had been of a unique character (Briggs 1996, 80-82). Most of the immigrants of the 1930-1960s period were Europeans fleeing from

\section{Table 1. The Foreign-Born Population of the United States, 1900-2000}

\begin{tabular}{ccc} 
Year & Number (Millions) & Percentage of Population \\
\hline 1900 & 10.3 & 13.6 \\
1910 & 13.5 & 14.7 \\
1920 & 13.9 & 13.2 \\
1930 & 14.2 & 11.6 \\
1940 & 11.5 & 8.8 \\
1950 & 10.3 & 6.9 \\
1960 & 9.7 & 5.4 \\
1965 & $8.5^{2}$ & 4.4 \\
1970 & 9.6 & 4.7 \\
1980 & 14.0 & 6.2 \\
1990 & $19.8^{2}$ & 7.9 \\
2000 & $28.4^{\mathrm{a}}$ & $10.0^{\mathrm{a}}$ \\
& $31.5^{\mathrm{b}}$ & $11.1^{\mathrm{b}}$ \\
\hline
\end{tabular}

Sources: U.S. Census Bureau (except for the year 1965, which is based on an estimate by Jeffery S. Passel (1995)).

"Data are based on Current Population Survey for March 2000 (a sample) (Census Bureau 2001).

${ }^{b}$ Data are from the actual 2000 population count released by the Census Bureau in 2002 (2002b). 
the onset and aftermath of Nazism and Fascism on their continent. In present-day terms, most would be known as refugees, but at the time the United States did not have any provisions for refugee admissions. Hence, those admitted entered only under the quotas allowed for their country under the terms of the prevailing Immigration Act of 1924 (also known as the National Origins Act).

Unlike the immigrants who preceded them (i.e., those who entered during the 1890-1920s era who were mostly poor rural peasants from eastern and southern Europe), the immigrants of the 1930-1960 era were overwhelmingly from the middle and upper economic classes and mostly from urban areas. They were disproportionately white-collar workers drawn from professional, business, arts, and academic backgrounds. Indeed, over this 30-year span the occupational category at the time of entry that accounted for the highest percentage of the immigrants was "professional, technical, and managerial." It is the only time in U.S. history up to that time that this highly skilled and educated classification was the major source of immigrants. Moreover, the country that supplied the largest number of immigrants during this period was Germany-an ethnic feature of immigrants that had not occurred since the 1880 s.

Hence, there was no reason in 1964 to expect that immigration policy would undermine efforts of the United States to exorcize itself of the blight of poverty among its citizens. The size of the foreign-born population was at an all time low (in percentage terms), and those that had entered over the preceding 30 years were disproportionately well endowed in terms of their human capital attributes.

\section{Policy Change with Unexpected Consequences}

The Immigration Act of 1965 was enacted and everything changed. It was another major legislative accomplishment of the Great Society (Briggs 1996, chapters 5 and 6). This act eliminated the overt discrimination associated with the national origin admission system that had characterized U.S. immigration policy since 1924. Immigration quotas for European countries had been set in a manner whereby those who received most of the available entry visas were persons from countries in northern and western Europe; the quotas from eastern and southern European nations were severely limited. Immigration from Asia had been essentially banned by earlier legislation (chapter 4). As the year before the Johnson Administration had also succeeded in passing the historic Civil Rights Act of 1964 to end overt discrimination within the nation, the next logical step was to purge it of its external discriminatory policies toward the rest of the world as embodied in its prevailing immigration policies. The Immigration Act of 1965, therefore, was as much a manifestation of civil rights policy as it was an instrument of immigration reform.

The immigration reform movement of the early 1960s was not designed to increase the level of immigration. No one wished to return to the "open door" immigration policies of the pre-1924 era. Instead, the goal was to create a non-discriminatory admission 
system for the entry of 290,000 persons (plus their immediate family relatives) each year. Senator Edward Kennedy, the floor manager for the Immigration Act of 1965, stated that its passage was "not concerned with increasing immigration to this country;" "nor will it lower any of the high standards we apply in the selection of immigrants;" "nor would our cities be flooded with a million immigrants annually;" nor would "the ethnic mix of this country be upset;" nor would "American workers lose their jobs" as a consequence of its passage (Briggs 1996, 114). Subsequent events were to demonstrate that none of his assurances were valid.

Although the details as to why the legislation had unexpected consequences are too complex to discuss in this context (see Briggs 1996, chapter 7, for an explanation), the principle reasons are as follows:

1. The legal entry system (introduced in 1965), which gives overwhelming preference to family reunification (of both immediate and extended family members) without regard to their human capital attributes.

2. The addition of the diversity lottery admission category (since 1991), which selects 55,000 immigrants each year solely because they happen to live in countries with low immigration rates to the United States and not with regard to their human capital attributes.

3. The massive violation of existing immigration ceilings by mostly poor persons who illegally immigrate.

4. The granting since 1986 of seven amnesties to 6 million persons-mostly from impoverished backgrounds- who previously had entered the country illegally or overstayed various temporary admission programs.

5. The extensive admission of refugees, mostly from third world nations.

6. The arrival of many poor persons, also from mostly from the third world, who often falsely make claims for political asylum to justify their presence and then abscond before their hearing dates are held or, if they receive a negative ruling, after being ordered to depart.

As a consequence of post-1965 legislation, the size of the foreign-born population had soared to 31.1 million persons in 2000 (Census Bureau $2002 \mathrm{~b}, 1$ ). This figure is a 57 percent increase in the size of the foreign-born population in 1990. By 2000, the foreign born accounted for 11.1 percent of the total population and 12.4 percent of the labor force.

But of even greater consequence than their total numbers is the fact that the preponderance of the post-1965 immigrants have been unskilled, poorly educated, and non-English speakers. Studies done by the National Research Council (NRC) of the National Academy of Sciences as background work for the U.S. Commission on Immigration Reform (chaired by Barbara Jordan) found that the educational attainment levels of post-1965 immigrants have steadily declined since 1970. Consequently, foreign-born workers, on average, earn less than native-born workers, and the earning 
gap has widened over the years (1997, 181-185). Immigrants from Latin America (including Mexico), which presently account for more than half of the entire foreign-born population of the nation, earn the lowest wages. The NRC, however, found no evidence of discriminatory wages being paid to immigrants (181). Rather, it found that immigrant workers are paid less than native-born workers because, in fact, they are less skilled and less educated. The relative declines in both skills and wages of the foreign-born population were attributed to the fact that most immigrants are coming from the poorer nations of the world, where the average education, wages, and skill levels are far below those in the United States (235-236). The NRC also found that since 1980 almost half of the decline in the real wages for native-born high school dropouts (i.e., unskilled workers) could be attributed to the adverse competitive impact of unskilled foreign-born workers (227). These finding supported the 1994 conclusions of the Council of Economic Advisers, which found that "immigration has increased the relative supply of less-educated labor and appears to have contributed to the increasing inequality of income" (120). Although their report claims that the aggregate effect on the national distribution of income is "small," immigration is a major sectorial factor in the deterioration of wages and incomes for low wage and low income families. Such is especially the case in large urban centers where immigrants have congregated. Indeed, a subsequent study by the Bureau of Labor Statistics in 1995 found that "immigration accounted for approximately 20 to 25 percent of the increase in the wage gap between low and high-skilled workers during the 1980s in the 50 largest metropolitan areas of the United States" (Jaeger 1995, 21).

The chief beneficiaries of post-1965 immigration are the immigrant workers themselves, whose wages are usually considerably higher than if they had stayed in their homelands, and businesses, who can hire workers at lower wages than would otherwise be the case. The chief losers are the native-born unskilled workers who have to compete with them. The NRC study also documented the fact that the fiscal costs of post-1965 immigration significantly exceed the alleged benefits (i.e., the suppression of wages for American workers from what would have otherwise have happened-a "benefit" that only economists can appreciate) of the immigration inflow. These fiscal costs were associated with increased education, medical, welfare, incarceration, and public housing costs that exceeded the taxes paid by immigrants themselves for these services (1997, 153 and 293). These fiscal costs are disproportionately distributed among the taxpayers in local communities and states depending on the size of the foreign-born population in their respective jurisdictions. California was the state that was the worst harmed.

For these reasons, it is not surprising to learn that the poverty rate of the foreign born in 2001 was 16.1 percent compared with 11.1 percent for the native-born population that year, or 45 percent higher (Census Bureau 2002a). Moreover, one-fifth (20.3 percent) of all children living in the United States in 1997 were reported to be living in poverty (Vleminckx and Smeeding 2001, 47). Among all industrialized nations in the world, only Russia had a higher percentage of impoverished children (23.2 percent). Within the United States, New York (26.3 percent) and California (25.7 percent) had 
the highest incidences of child poverty (Vleminckx and Smeeding, 49). It is no accident that the two states accounted for almost half ( 45.5 percent) of the nation's total foreign-born population in 2000. In New York, for instance, children with foreign-born parents represented 48 percent of poor children in New York City and 39 percent statewide.

Therefore, it is apparent that inmigration policy-which is entirely a discretionary action of the federal policy makers-has since 1965 become a significant contributor to the perpetuation of the nation's poverty population as it enters the twenty-first century.

\section{Conclusion}

Efforts in the United States to reduce the incidence of poverty have been hampered, since 1965 , by the parallel revival from out of the nation's distant past of the phenomenon of mass immigration. As a consequence, any serious attempt to reduce poverty must now include comprehensive reforms in the nation's immigration policies if they are to be taken seriously. Among the most prominent of these would be the implementation of the main recommendations of the U.S. Commission on Immigration Reform (1997). These include lowering the level of legal immigration, reducing the emphasis on family reunification by terminating the preference categories for extended family members, eliminating all admissions of unskilled workers from the occupational preferences, and including refugees in the overall immigration admission ceiling for each year (Commission on Immigration Reform 1995). Remedies must also provide for enforcement of existing immigration laws by enhancing border control to prevent illegal entry, rigidly enforcing employer sanctions against hiring illegal immigrants already in the country, and stepping up efforts to deter the use of fraudulent documents by job seekers who are illegal immigrants. Furthermore, there should be no more grants of amnesty to those who have illegally entered the United States. The repeated amnesties since 1986 have given the impression that there is little reason for persons who fail to qualify for entry not to come and to bide their time until, for expediency reasons, the politicians enact yet another amnesty. Lastly, efforts must be made to apprehend those who fail to appear or who abscond after receiving unfavorable rulings in political asylum cases and to deport them.

As for those who would be denied entry under these reforms, the United States could adopt other policies to address the root causes of poverty in their homelands. Among these would be enhanced economic development assistance, trade concessions, and linkages of trade with the United States to adherence to international human rights standards by their governments, as well as support for family planning information and the extensive provision of contraceptive means. But the answer to world poverty simply cannot be immigration to the United States. Such access does nothing to reduce the pressures in those source countries for pcople to leave, and it only harms the poor in the 
United States who have to compete with the poor from abroad for jobs and social services.

Unless comprehensive immigration reforms are added to the arsenal of anti-poverty policies, efforts to reduce poverty in the country in the twenty-first century will be little more than a ride on a squirrel wheel-a lot of effort expended but little progress achieved.

\section{References}

Briggs, Vernon M., Jr. Mass Immigration and the National Interest. 2 d ed. Armonk, N.Y.: M. E. Sharpe, Inc, 1996. Council of Economic Advisers. Economic Report of the President: 1994. Washington, D.C.: U.S. Government Printing Office, 1994.

Jaeger, David A. "Skill Differences and the Effect of Immigrants on the Wages of Natives." Working paper no. 273, Burcau of Labor Statistics, Washington, D.C.: U.S. Department of Labor, Bureau of Labor Statistics, 1995.

Levitan, Sar A. The Great Society's Poor Law: A New Approach to Poverty. Baltimore: The Johns Hopkins University Press, 1969.

National Rescarch Council. The New Americans: Economic, Demographic, and Fiscal Effects of Immigration, edited by James P. Smith and Barry Edmonton. Washington, D.C.: National Academy Press, 1997.

Passel, Jeffery S. "30 Years of Immigration and U.S. Population Growth." Paper presented at the annual meetings of the Association for Public Policy Analysis and Management, Washington, D.C., November 1995.

U.S. Census Bureau. "Historical Census Statistics on the Foreign-Born Population of the United Statcs: 1850 to 1990." Population Division working paper 29. Washington, D.C.: February 1999.

U.S. Census Bureau. Profile of the Foreign-Born Population in the United States: 2000, 23-206. Washington, D.C.: U.S. Government Printing Office, 2001.

—. Poverty in the United States: 2000, 60-219. Washington, D.C.: U.S. Government Printing Office, 2002 a.

—. "Number of Foreign-Born Up 57 Percent Since 1990 According to 2000 Census." Commerce News. Washington, D.C.: U.S. Department of Commerce, $2002 \mathrm{~b}$.

U.S. Commission on Immigration Reform. Legal Immigration: Setting Priorities. Washington, D.C.: U.S. Commission on Immigration Reform, 1995.

- Becoming an American: Immigration and Immigrant Policy. Washington, D.C.: U.S. Commission of Immigration Reform, 1997.

Vleminckx, Koren, and Timothy M. Smeeding. Child Well-Being, Child Poverty, and Child Policy in Modern Nations. Bristol, U.K.: The Policy Press, 2001. 